\title{
КОРРУПЦИЯ И ЗАКОНОДАТЕЛЬСТВО: АНАЛИЗ ЗАКОНА НА КОРРУПЦИОГЕННОСТЬ
}

\author{
(c) 2021 Казанкова Татьяна Николаевна \\ кандидат педагогических наук \\ Самарский государственный экономический университет, Россия, Самара \\ (c) 2021 Егорова Анастасия Сергеевна \\ магистрант \\ Самарский государственный экономический университет, Россия, Самара
}

\begin{abstract}
Анализ закона на коррупциогенность является достаточно актуальным вопросом в государстве. Принимая нормативно-правовые акты с двусмысленной трактовкой, законодатель создаёт возможность должностным лицам трактовать их в своих интересах. Поэтому предоставляя в распоряжение эксперта нормативно-правовой акт с целью установления наличия в нём коррупциогенных факторов, мы вполне можем наблюдать динамику снижения коррупционных преступлений в государстве.
\end{abstract}

Ключевые слова: закон, коррупция, коррупциогенные факторы, нормативно-правовой акт, антикоррупционная экспертиза, противодействие

Коррупционные действия проявляются во всех сферах жизни нашего государства, затрагивая отношения, как на бытовом уровне, так и на политическом. Зарождение антикоррупционного законодательства приходится на конец $\mathrm{XX}$ века. Однако огромную роль в борьбе с коррупционными явлениями заслуживает Федеральный закон № 273-Ф3 « О противодействии коррупции», который был принят 25 декабря 2008 года, который в должной мере учредил основные положения, направленные на противодействие проявлениям коррупционных факторов в государстве.

В настоящий момент дефиниция «коррупция» имеет достаточное и вполне конкретное закрепление в нормах Федерального закона № 273-Ф3 «О противодействии коррупции» от 25.12.2008 года. Законодатель трактует коррупцию как злоупотребление служебным положением, дача взятки, получение взятки, злоупотребление полномочиями, коммерческий подкуп либо иное незаконное использование физическим лицом своего должностного положения вопреки законным интересам общества и государства в целях получения выгоды для себя или для третьих лиц либо незаконное предоставление такой выгоды указанному лицу другими физическими лицами [1]. Законотворец не ограничился данным понятием в отношение только физических лиц, также им предложено рассматривать перечисленные деяния в интересах юридического лица или от его имени. Рас- сматривая коррупционные нарушения в рамках уголовного права, становится очевидным труднодоказуемость данных преступлений, именно этим обосновывается роль превентивных мер борьбы с коррупцией.

Огромное значение для борьбы с коррупционной составляющей в стране играет формирование чёткого законодательства, которое препятствует совершению государственными служащими различных махинаций. Таким образом, необходимо добиться конкретной формулировки законов и подзаконных нормативноправовых актов, не предоставляющей возможности произвольных действий и лоббирования интересов третьих лиц.

На практике доказано, что невозможно противодействовать коррупционным явлениям отдельными профилактическими мероприятиями, необходимо реализовать целый ряд мер борьбы, что в результате приведёт к снижению уровня коррупции в государстве. В качестве первоочередных мер борьбы необходимо обратить внимание на определение теоретических и методологических причин, уяснение, а также создание и реализацию новейших технологий, разработанных на основе научного анализа, которые вполне можно признать инструментами с эффективными результатами борьбы с коррупционной деятельностью.

Неоднократно поднимался вопрос о выделении в российском законодательстве новой отрасли права, предметом изучения которой яв- 
ляется коррупция. Говоря о потребности в новой отрасли права, данную мысль разделяет профессор Комарова А.И., предлагая способ упорядочения законодательства в сфере коррупции, кодификации уже действующих нормативных актов в единую и согласованную систему [2]. Заслуженный юрист РФ Лахман А.Г. в качестве рационального способа внедрения новой отрасли предлагает институционализацию, поскольку данный процесс предполагает формирование свода определённых правил и норм, а принятые и действующие на данный период нормативноправовые акты различной юридической силы как раз являются подтверждением сложившейся комплексной правовой отрасли [3].

Наиболее часто признаки коррупции прослеживаются в публичных отраслях российского законодательства, например финансовое, таможенное, налоговое право, где присутствует процедура распределения денежных средств и вертикальные правовые отношения, то есть отношения «государство-гражданин» или «государство-организация». Не стоит обделять вниманием коррупционные махинации в частной деятельности, примером данного проявления может служить передача функций государства некоммерческим организациям на аутсорсинг. В результате чего коррупция приобретает модель посредничества между бизнесом и государством, что, безусловно, приводит к негативным последствиям, которые проявляются в ненадлежащем выполнении организациями своих функций и неэффективности государственного управления.

K сожалению, необходимо согласиться с фактом принятия законов с двусмысленной трактовкой содержащихся норм, несущих в себе некую лазейку для лиц, склонных к коррупционным махинациям и уклоняющимся от ответственности. В качестве базиса развития коррупции в стране можно выделить пробелы и дефекты законов и подзаконных нормативно-правовых актов, которые возникают по причине невнимательности, а также в связи с допущением правотворческими органами юридических ошибок и неточностей. Необходимо отметить, что при установлении коррупциогенных факторов зачастую возникают трудности, поскольку не всегда удаётся установить умышленно или по невнимательности в нормах нормативно-правового акта содержатся некие «лазейки». Впрочем, несмотря на официальное закрепление коррупциогенных норм внешне по форме легальных, а в действительности - нелегальных позволяет рассматривать их в качестве составляющей презумпции совершения действий, противоречащих закону. Коррупциогенный фактор следует рассматривать как юридическое предписание, в котором заложены задатки, порождающие противоправные деяния в коррупционной сфере.

Дефиниция «антикоррупционная экспертиза» и процесс анализа нормативно-правового акта неразрывно связаны, поскольку в качестве цели экспертизы и анализа выступает установление наличия в положениях документа факторов, имеющих коррупционную составляющую. Следовательно, процесс анализа является составной частью антикоррупционной экспертизы.

Антикоррупционная экспертиза нормативно-правовых актов является одной из превентивных мер борьбы, предупреждающих распространение коррупционных начал в государстве. Её предназначение заключается в том, что у эксперта при мониторинге положений закона появляется возможность обнаружения коррупциогенных факторов. На самом деле антикоррупционную экспертизу можно рассматривать с двух сторон. С одной стороны, она выступает в качестве способа, позволяющего выявить факторы коррупции, с другой - ориентирована на выполнение превентивной меры борьбы с незаконными проявлениями.

Организация и непосредственно сама процедура антикоррупционной экспертизы зафиксирована в Федеральном законе № 172-ФЗ «Об антикоррупционной экспертизе нормативных правовых актов и проектов нормативных правовых актов» от 17.07.2009 года, следовательно, данная процедура выступает в качестве обязательства для органов федерального и регионального значения, принимающих нормативно-правовой акт, отступление от данного правила выступает в качестве ненадлежащего исполнения предписаний, однако, непроведение экспертизы уже действующих в государстве до момента принятия Федерального закона нормативно-правовых актов нарушением не является.

Оценивая закон на коррупциогенность, в ходе экспертизы перед экспертом ставятся следующие задачи:

- выявить коррупционные составляющие, а также пробелы и дефекты норм проекта нормативно-правового акта; 
- при выявлении коррупциогенных факторов разработать и аргументировать рекомендации по устранению нарушений и включению в положения закона превентивных норм (при их отсутствии);

- предварительно оценить криминологическую обстановку после вступления в силу нормативно-правового акта;

- выявить нормы, а также отдельные положения правового акта, которые противоречат или не соответствуют национальным и международным антикоррупционным стандартам;

- определить возможную эффективность борьбы с коррупционными правонарушениями.

Проведение анализа является достаточно трудоёмкой и комплексной работой, поэтому проводится в несколько этапов. Первый этап включает в себя предварительный анализ правовых отношений, которые регулируются данным нормативно-правовым актом, исследование и изучение судебной практики данной сферы, способов проявления коррупции в деятельности органов государственного управления и должностных лиц.

Первоначально эксперту необходимо установить присутствуют ли атипичные компоненты коррупционности в нормативно-правовом акте и в отдельных положениях.

В качестве способа проведения заключительного этапа выделяют анализ нормативноправового акта по существу. Для того чтобы обеспечить обоснованность, объективность итогов оценки коррупциогенности нормативноправового акта необходимо прибегнуть к анализу на предмет наличия коррупциогенных признаков отдельную норму нормативноправового акта.

В случае если после окончания антикоррупционной экспертизы экспертами будет установлено наличие в нормативно-правовом акте коррупционных признаков, то проработанный документ по праву признаётся не соответствующим общепринятым антикоррупционным правилам, поскольку в его содержании выявлены потенциальные риски коррупции при применении на практике.

Говоря об анализе нормативно-правового акта на наличие коррупциогенных факторов, не стоит забывать о документообороте, так как при реализации одного документа зачастую требуется принятие и рассмотрение иных документов. В качестве меры их законности и правомерно- сти выступают нормы законов правительственных и ведомственных актов, которые содержат в себе правила их подготовки, представления и рассмотрения, а также виды и их значение. Но, несмотря на это, по-прежнему, имеются созданные государством препятствия вследствие деформации документооборота.

Антикоррупционный мониторинг является относительно новой превентивной мерой борьбы с коррупцией. Целью данного мониторинга выступает обнаружение всевозможных недочётов и ошибок, которые характеризуются наличием коррупциогенности. В данный момент на базе Совета Федерации Федерального Собрания РФ функционирует Центр мониторинга, данные центры осуществляют свою деятельность и в Самарской области, и Ставропольском крае, и в других регионах государства.

В российском государстве предусмотрена не одна, а несколько методик, в соответствии с которыми реализуется антикоррупционная экспертиза, поскольку коррупция для государства представляет серьёзную проблему. Буквально в 2019 году в практику была внедрена новая методика антикоррупционной экспертизы, где были приняты во внимание рекомендации Института законодательства и сравнительного правоведения.

По завершению анализа закона на коррупциогенность в заключении должны быть отражены следующие обязательные пункты:

- в случае выявления коррупции должны быть перечислены факторы;

- отражена степень проявления коррупциогенных признаков (низкая, средняя, высокая);

- предложения разработчикам, носящие рекомендательный характер, например, устранить выявленных признаки коррупции, организовать проведение дополнительной экспертизы.

Вынесенный по итогам оценки нормативноправового акта результат должен быть рассмотрен уполномоченным на это государственным служащим, принимая во внимание действующий регламент. В случае непринятия мер реагирования на предписанные рекомендации, следует рассматривать данное действие как нарушение в форме служебного проступка.

Таким образом, анализируя материал по данной теме, следует отметить, что борьба с коррупционной составляющей должна пронизывать все отрасли российского права. Реализуя отдельные профилактические мероприятия по 
противодействию коррупции, невозможно искоренить такое масштабное явление, поэтому необходимо использовать превентивные меры борьбы, пронизывающие всё российское законодательство.

Учитывая то, что российское законодательство включает в себя в основном общие положения об антикоррупционных экспертизах нормативно-правового акта, стоит уделить внимание ведомственным и региональным программам по борьбе с законотворческой коррупцией. Было бы уместно включить в систему права новую отрасль, предметом изучения которой является коррупция и все её составляющие. Необходимо официально признать антикоррупционную экспертизу обязательной процедурой, обязательным этапом подготовки любого нормативно-правового акта. Анализ закона на коррупциогенность является эффективной мерой борьбы с коррупционной составляю- щей в государстве, поскольку эксперт, исследуя текст нормативно-правового акта, работает на опережение, то есть, выявляя и устраняя наличие коррупциогенных факторов, он выступает своего рода барьером антикоррупционного законодательства Принимая во внимание вышеперечисленные рекомендации в качестве меры противодействия коррупции оценка нормативно-правового акта на коррупциогенность будет выступать результативным показателем профилактики коррупции в федеральных органах исполнительной власти. Предотвращая появление в системе законодательства новых нормативно-правовых актов с коррупциогенными признаками, российское государство смело может рассчитывать на снижение уровня коррупционных преступлений, а также на добросовестную деятельность служащих всех уровней власти.

\section{Библиографический список}

1. Федеральный закон «О противодействии коррупции» от 25.12.2008 г. № 278-Ф3 [принят Гос. Думой 19.12.2008 г.: одоб. Советом Федерации 22.12.2008 г.] База данных «Консультант Плюс». Retrieved from: http://www.consultant.ru/document/cons_doc_LAW_82959/ (дата обращения: 10.09.2020)

2. Комарова А. И. Антикоррупция в России сегодня: праксеологический, аналитико-прогностиче-ский аспект // Вестник Московского университета им. С. Ю. Витте. Серия 2: Юридические науки. 2014. № 2 (5). Retrieved from: https://elibrary.ru/item.asp?id=23400699 (дата обращения: 10.09.2020)

3. Лахман А.Г. Коррупция и противодействие коррупции: проблемы правопонимания// Власть и управление на Востоке России//. 2013. Retrieved from: https://cyberleninka.ru/article/n/korruptsiya-i-protivodeystviekorruptsii-problemy-pravoponimaniya (дата обращения: 12.09.2020) 